\title{
'IT IS NEW, AND IT HAS TO BE DONE!': SOCIO-ANALYTIC THOUGHTS ON BETRAYAL AND CYNICISM IN ORGANIZATIONAL TRANSFORMATION
}

\section{Burkard Sievers}

Schumpeter School of Business and Economics, Bergische Universität Wuppertal

Prof, emeritus Dr. Burkard Sievers

Authorized re-publication from: Culture \& Organization 13(1), 1-27
Recebido em: 19/12/2008

Aprovado em: 14/04/2009

\section{ABSTRACT}

Contemporary western organizations appear to be caught in neophily, i.e., a cult of newness and novelty. As traditional means of organizational transformation - and profit maximization in particular - have broadly proven insufficient or to have completely failed, contemporary capitalism has turned the Old into an antiquated object of hatred. As the Old, and thus the past, is split off, the New - because it is new - is guaranteed to be better. Organizational structures and processes that previously served as more or less reliable containers for both labour and capital are now regarded as old wineskins that have served their purpose and belong on the 'scrapheap of history'. This paper emanates from the working hypothesis that betrayal and cynicism, in the context of organizational transformation, cannot sufficiently be understood from a perspective limited to individual psychopathology but has to take the organization as a whole into account.

Keywords: Betrayal, Cynicism, Organizational Transformation, Socio-analysis.

'Newness' is a powerful rhetorical trope in the western civilization. We live in a culture that values new findings, new ideas and new clothes and where that which is old tends to be regarded as obsolete. (EriKsson, 2002: 10)

Issues of betrayal always involve central processes of change and stability in the moral and social boundaries of collectives of people and hence in their sense of belonging and identity. (BEN-YeHUDA, 2001: 311ff)

Cynicism results when one is no longer prepared to experience betrayal, and it functions to immunize oneself against further injuries of this kind. (TEICHERT, 1990: 100)

\section{INTRODUCTION}

The idea of focusing this paper on the organizational function and meaning of betrayal and cynicism in the context of 'the New' originates to some extent from my experience of consulting to the 'Social Democratic Party of Austria (SPÖ)' a few years ago (SIEVERS, 2006). Many of the dreams shared during the Social Dreaming Matrix (LAWRENCE, 1998) ${ }^{1}$ referred to the participants' experience of being severely betrayed by their political party. As this became obvious through their associations to the dreams, the Austrian Social Democratic Party appeared to have given up not only its original name 'Socialist Party' but also most of the essential ideas of socialism. The ongoing effort of their

Endereço do autor:

\footnotetext{
1 Social Dreaming 'is a discipline for discovering the social meaning and significance of dreams through sharing them with each other's. This is done by the deliberate and sustained method of free association and amplification through the Social Dreaming Matrix.... From the inception of Social Dreaming the systemic nature of dreaming was recognized and affirmed. Not only do dreamers dream from their ecological niche but also they dream themes that are systemically related. Social dreaming is also a uniquely experiential discipline, which frees participants from their personal defenses that constrain free-thinking and interaction in ordinary social situations. Social dreaming can be used in organizational systems, professional communities, and consumer, focus and special interest groups' (quoted from the text of the Social Dreaming Institute). Social Dreaming was founded by W. Gordon Lawrence in 1982.
} 
political party to pursue a policy of moderation in order to gain the centre and thus the majority of votes in the elections made them suspicious and full of anger and rage. As one participant of the Social Dreaming Matrix expressed it: 'We should fight against our corrupt party, a system that exists. I have lost the dream, the vision of what Social Democracy embodies. There is nothing more worth fighting for. What is important has already been accomplished; we don't have to fight for it' (SIEVERS, 2006). While the participants at first expressed their disappointment with the party leaders, they later realized that they were not only the betrayed victims but were also playing an active role in this betrayal of the idea of socialism.

Though this Social Dreaming example would be worth much further elaboration in the context of contemporary political betrayal in democracy at large, the emphasis of this paper is the broader issue of how the introduction and implementation of the New in organizational transformation often is met by the experience of betrayal that, in addition to many other reactions, may induce cynicism. This is, as one easily may assume, particularly the case if those at the top enforce the New by destructive social and managerial engineering. This paper thus focuses on some of the underlying organizational psychodynamics that result from the neglect, violence, persuasion, manipulation, and lack of thinking which often determines the social atmosphere of transformational processes and ventures in organizations.

Instead of dealing with the phenomena of betrayal and cynicism in the traditional frame as a psychic expression of 'resistance to change' - a frame that primarily focuses on the inner world of individuals and their reactions towards organizational change my attempt at understanding these phenomena as 'social facts' is guided by a socio-analytic perspective. ${ }^{2}$

The following thoughts thus emanate from the working hypothesis that betrayal and cynicism, in the context of organizational transformation, cannot primarily be regarded as the outcome of individual psychopathology. As these organizational transformations mainly are imposed and engineered by top

\footnotetext{
2 Socio-analysis is defined 'as the activity of exploration, consultancy, and action research which combines and synthesises methodologies and theories derived from psychoanalysis, group relations, social systems thinking and organizational behaviour' and 'social dreaming' (BAIN, 1999: 14).
}

management, the experience and reaction of betrayal and cynicism towards the New on the side of subordinate organizational role holders have to be perceived as being socially induced; betrayal and cynicism are part of the organization as a whole and thus have an impact on its role holders.

Though, as will be further elaborated, the implementation of the New is often accompanied by a splitting of new and old in the sense that 'all that is new is deemed progressive and all that is old regressive' (GILmore, Shea and Useem, 1997: 40), I hope that the following thoughts are not seen as going from the frying pan into the fire by seeming to advocate a reverse splitting, i.e., only the old is good and the new bad.

As with previous topics I have studied (e.g., secrecy in organizations, competition as war, the economy of vengeance and the misuse of trust in organizations Sievers, 1974, 2000, 2003a, 2003b, 2003c; Sievers and Mersky, 2004, 2006), there apparently is an enormous gap between the frequency with which social phenomena like betrayal and cynicism appear in everyday life and the attention actually paid to their scientific conceptualization and understanding. Not only is betrayal quite common throughout the history of mankind and found symbolically in many myths, narratives, literature (e.g., vON MATT, 1989) and a variety of arts, we all obviously have a whole range of often tragic personal experiences of betrayal. 'The consequence of betrayal in familiar contexts, is, as Luhmann has pointed out, that the familiar itself is shattered:..."A gulf opens up even with respect to things and people nearest to one, which doubt removes into a surprising strangeness" (1979: 33)' (AKERSTRÖM, 1991: 20). Whereas being the victim of betrayal results in the experience of disappointment of trust and may raise feelings of loss, anger, rage, despair, the desire for revenge, cynicism or even traumatization, acknowledging one's own betrayal of an idea or towards others is not easy and is seldom accompanied by shame and remorse. Not least, 'we are betraying ourselves; we betray what we once were willing to do and for what we have fought' (JAEGGI, 1984: 302).

A first literature search gives the impression that betrayal is almost ubiquitous - an impression that may be confusing at first sight but makes further sense if one follows the wider understanding of the Italian Jungian psychoanalyst, Carotenuto (1996: 14): 'life as betrayal constitutes a key to understanding all pheno- 
mena making up the existence of an individual'. 'The shadow of betrayal looms over the origin of individuality' (ibid.: 15).'Life in itself, from the moment of birth, is betrayal' (ibid.: 25; cf. GreEN, 1978: 182).

There is, both in contemporary fiction and nonfiction literature, not only an endless amount of books on the betrayal of love and adultery, but countless references to betrayal from a broad range of perspectives. Not only are spies, politicians, governments, the media, or the (Catholic) Church (e.g., Boston Globe, 2003) accused of betrayal. Other objects of betrayal include 'the American man' (Faludi 1999), American sovereignty and social justice (BuCHANAN, 1998), democracy (LASCH, 1995), modern work (CIULla, 2000), the worker (Wolman and Colamosca, 1997), global public health (GARRETt, 2000), freedom (BERLIN, 2002), and not least confidentiality in psychoanalysis and psychotherapy (Bollas and SUNDELSON, 1995). And, not too surprisingly, there are also countless self-help and how-to-avoid books both by (amateur) therapists and organizational consultants (e.g., Reina and Reina, 1999; Zyman and Brott, 2004).

It well may be that since 'one of the features of betrayal is its normality and commonness' (AKERSTRÖM, 1991: xii), it seems to have been broadly ignored as a topic of the social sciences. It is quite surprising that since Georg Simmel's (1907: 3ff, 1908: 342ff, 1950: 294ff) explicit reference to betrayal as 'the logical contrary to the secret', sociology, with very few exceptions (e.g., GresSON, 1982; AKERSTRÖM, 1991; BEN-YEHUDA, 2001), seems to have been broadly silent on betrayal - and on secrecy (cf. SieVers, 1974; LuDz, 1979). Psychological and psychoanalytical inquiries in particular are also scarce and mainly restricted to a personal or interpersonal perspective, emphasizing the harm, the pain, and the trauma of the betrayed. This is equally true for cynicism. There is little literature that explicitly deals with it from a psychoanalytic perspective. From the few sources I have been able to make out - Reik, 1930/[1913]; Bergler, 1933a, 1933b; Sarnoff, 1960; Bonime, 1966; Eiguer, 1999 - cynicism either is regarded as an expression of individual psychopathology or referred to in a pejorative sense.

As already mentioned and indicated by the first line of the this paper's title, 'It is new, and it has to be done!', special emphasis will be laid on how, in the context of organizations, the introduction of new strategies, policies, and value systems is often experienced as betrayal. If they do not have means and capacities to deal in another way, people react with cynicism. This reaction seemed connected to the way in which the New is often praised and perceived as a panacea in the sense that newness and novelty per se are considered to be better than the Old. One example of the ' $I t$ ' referred to in the first part of the title is 'reengineering', which is widely praised by Peter Drucker on the front of the book jacket of Hammer and Champy's (1993) book on reengineering as a 'manifesto for business revolution'.

To the extent that the experience of betrayal and cynicism predominates in organizations, the social bonds necessary for productive and meaningful work are damaged, which is most likely devastating for an organization's success, profit, and shareholder value. Even though betrayal and cynicism are not new phenomena in relationship to organizational transformation their contemporary predominance must as will be further elaborated towards the end of this paper - partly be understood as part of the global psychotic dynamic created and maintained by the more recent financial service revolution.

\section{BETRAYAL AND CYNICISM IN PSYCHOANALYSIS \\ Betrayal}

Betrayal in the context of psychoanalysis has at least a twofold aspect. It is both the object of analysis and research as well as the content of extensive reproaches. Both Freud himself (in the case of DORA - FREUD, 1905) and other psychoanalysts have - for good or bad reasons - been accused of the abuse and betrayal of patients. As Westerlund (1986), for example, explicates, seduction and betrayal of patients have a long history.

As psychoanalysis (and psychology) - with their 'retrospective, pathological bias which makes them apter for explaining the present in terms of the past' (RYCROFT, 1992: 17) - traditionally focuses on the individual, it is not surprising that betrayal in psychoanalysis mainly seems to be restricted to the context of selfbetrayal and betrayal trauma. As Josephs (2001: 705) indicates, Freud (1919) made already 'explicit that the child views parental intercourse as an act of infidelity, as sexual betrayal'. The 'primal scene' is experienced as a betrayal of trust that destroys the 
assumption of being the unique centre of the parents' love and protection. The experience of betrayal may put the child in a kind of double bind situation of being neither able to keep the full awareness of betrayal nor to 'express' it due to the (unconscious) fantasy of betraying his/her parents.

Following Otto Rank's (1952/[1924]) thoughts in The Trauma of Birth, Carotenuto (1996: 9ff) regards birth-related betrayal as having a fundamental importance. 'Our existence and our autonomy are conditioned because, even before we come into the world, we have already been invented, invented by parents who also were invented. Betrayal, therefore, is inexorably transmitted down through the generations' (ibid: 11) - Carotenuto is one of the few psychoanalytic authors whose understanding of betrayal explicitly focuses on 'the vicious circle of betrayal, which is the family circle' (ibid.: 35). 'The primary context in which betrayal is experienced is the family, for it is in that nucleus that the first love pact is sealed' (ibid.: 43).

Not acknowledging and thus betraying the experience of being deceived is one of the sources of betrayal blindness that every child 'learns' to some extent very early in the individuation and socialization process. Betrayal blindness is, as Freyd (1996: 193) puts it, 'the systematic filtering of reality in order to maintain human relationships. It is the not knowing and not remembering the betrayals of everyday life and everyday relationships in order to protect those relationships. It includes the white lies - and the darker lies - we tell ourselves so as not to threaten our bonds'.

Self-betrayal, to which we all are prone to a larger or minor extent (GRUEN: 1988; HIRSCH: 1999), can be perceived as a form of perverted love. It is based on subjection and the denial of one's own needs and desires in order to receive (parental) recognition and love (cf. Mıller, 1996[1979], 1998/[1981]; Winnicott's $[1965,1967]$ notion of the 'false self'). It most likely becomes chronic for those lacking the basic experience of being loved for one's own self and who learned to subjugate themselves to their parents' aspirations in order to earn their love. The betrayal of self is similar to a vita reducta, a restriction of one's own liveliness that tends to be sublimated by permanently proving imaginary superiority. This compulsion and adaptation 'keep us from knowing ourselves and others fully.We end up fragmented both internally and externally - impoverished spiritually and socially'
(FreYd, 1996: 195). In its extreme case, self-betrayal may lead to a betrayal trauma, i.e., 'the realisation that one had been deceived and led astray by one's own forbidden but rationalised wishes, masquerading as one's conscience' (JosepHS, 2001: 703).

'The dread of betrayal trauma results in maintaining a constant state of suspicion in relation to whatever engenders a sense of trust and security' (ibid: 707). 'Part of the humiliation of self-betrayal is that one sacrificed the integrity of the self for a forbidden bliss that in reality is not blissful after all' (ibid.). As 'betrayal phenomena are partially a consequence of violations of certain compromises that the oppressed had endured (if not accepted gladly)' (GRESSON, 1982: $10)$, betrayal thus is not only a matter of who betrayed whom but raises 'the more profound questions of man's capacity for forming successful social bounds and how they are broken' (ibid.: 4).

Freyd $(1994,1996)$ especially focuses on the betrayal trauma of abused children, elaborating the quite curious blending of knowing and not knowing typical for betrayal and its traumatic escalation. 'The survivor of childhood abuse who "forgets" and does "not know" about the abuse similarly has memory and knowledge of the event that surface in other ways: specific phobias, learned behaviours, a self-perception of being a "bad girl" or "bad boy"' (FreYD, 1996: 4). The victim of a betrayal trauma also may be consciously or unconsciously facing the dilemma of being able to 'afford to know about the betrayal but does not know that such awareness is safe' (ibid.: 11). What Freyd (ibid:: 65) describes as the risk of a child in being fully aware of betrayal by a parent or caregiver, i.e., that it is 'or may seem to be, a matter of life and death', may, as will be elaborated later, be equally valid for role holders in organizations. The amnesia of betrayal, implemented by both personal and interpersonal mechanisms, creates " "information blockage" and a kind of knowing without knowledge' (Brenneis, 1997: 449) - even though Freyd does not explicitly refer to Bollas' (1987, 1989) concept of the 'unthought known', ${ }^{3}$ the proximity of her thinking is obvious.

\footnotetext{
${ }^{3}$ Unthought known is a term which has been offered by the British psychoanalyst Bollas (1987, 1989). It refers to what 'is known at some level but has never been thought or put into words, and so is not available for further thinking' (LAWRENCE, 2000: 11-12). This knowledge cannot be grasped because it
} 
Whereas elaborations on betrayal in psychoanalysis seem broadly restricted to its meaning for the individual, Bollas, the British psychoanalyst, significantly widens the frame of reference to the institutional and political realm. In his book, The New Informants, written with Sundelson, both authors describe to what extent institutional, legal and technical changes in the practice of psychoanalysis and psychotherapy have contributed to the betrayal of confidentiality in work with patients (Bollas and Sundelson, 1995). The analyst thus is in danger of becoming a cynic 'exploiting for personal ends his patient's need' (GREEN, 1978: 187).

Psychoanalysis, despite its ongoing emphasis on the legacy of Freud and other early psychoanalysts (cf., e.g., GrossKURTH, 1991; SIEVERS, 2001), has been in permanent fear of betrayal of the 'doctrine' since its very beginning; the excommunication of Carl Gustav Jung, Otto Rank and countless others as well as the founding of the committee of the seven rings 4 are only some of the episodes and dynamics that illustrate this - it appears that the fear of betrayal is further immanent - and thus widely inexpressible in psychoanalysis due to the specific socialization process of psychoanalysts and their transferences ${ }^{5}$ during the training analysis in particular.

Hillman (1964: 22), a Jungian, appears to be the only psychoanalyst who explicitly indicates the restrictedness of a psychological perspective on betrayal: 'Betrayal ... is too tragic an experience to be justified in personal terms of psychological mechanisms and motives. Personal psychology is not enough; analysis and explanations will not do'. Whereas most of the psychoanalytic literature appears to be limited to the

\footnotetext{
cannot be phrased in language or metaphor. As it cannot be thought, named, or put into an idea, it is acted out primarily in situations of high anxiety and chaos, which foster the exportation of the threat of internal terror.

4 The Committee of seven rings is "the "Secret Committee" of seven men, including himself, that Freud organized in 1912 "to maintain the faith and to search out deviance" from his principles. Freud charged Ernest Jones, Karl Abraham, Otto Rank, Sandor Ferenczi, Hanns Sachs and Max Eitingon with preserving his discovery and propagating it around the world. To seal their compact he gave each an ancient ring, thus closing the circle' (SCHNeIDERMAn, 1991).

${ }^{5}$ Transference: the process by which an individual or social system displaces on to others feelings, ideas, etc., by which it relates to others as though it were some former object (cf. RYCROFT, 1995/[1968]: 185ff).
}

traditional imagination of betrayal as sin, Hillman (ibid.: 21) refers to the possibility that 'the capacity to betray others is akin to the capacity to lead others' - a turn of the notion of betrayal according to which it - as further elaborated by Krantz (2005) - actually could be understood as a kind of creativity leading to organizational survival.

\section{Cynicism}

It will hardly be necessary, in the present context, to remind us that Freud and psychoanalysis are often attacked for inherent cynicism not only by the 'public' but, in some cases, by Freud's 'followers' (e.g., KAREN Horney). Or, as Sloterdijk (1988: 295) puts it, Freud 'erected a theory that makes us all, whether we like it or not, into kynics (if not even into cynics)'.

What is more important here is the impression that there is almost no explicit link between betrayal and cynicism in psychoanalytic literature. That the cynic in psychoanalytic literature is, for example, supposed to devalue in a nihilistic way what actually is of high value for him (HAUBL, 2001: 99) may well be an expression of self-betrayal. This also seems to be the case if 'the cynic is stated to possess an ethic of the negative, in which beauty is trampled underfoot by linguistic acts permeated with the subject's internal void' (EIGUer, 1999: 671). To the extent that cynicism as a linguistic act is supposed to have 'the specific purpose of serving as an alibi within a defensive strategy aimed at domination' (ibid.), it equally may serve the self-betrayer as a means to prove imaginary superiority. 'Any attachment would be futile, according to the cynic. If a human being seeks it out, the reason is weakness and the fear of loneliness and independence. Compassion, affliction and pain are no part of the cynic's world. He takes emotional paralysis to extremes, but the ultimate object is to avoid feeling separation anxiety' (ibid.).

'The cynic sets himself up as the founder of a different law, which is terrible and terrifying for his fellow human being, who is his victim and sometimes his accomplice. He claims to be the superego, an exterminating angel; his superego does not impose itself on his ego, but "is" the ego, whereas the actual ego is projected "narcissistically" outwards' (ibid.: 675). Eiguer (ibid.: 676) is convinced that cynicism 'is not merely a marginal phenomenon, but that it 
fills a void in a psychic structure that does not allow the patient to displace and symbolise like the neurotic: instead, he is induced to construct theories for himself, to support them by argument, and to prove them by enactment'.

'Cynicism is a subjective disbelief in the capacity of any human being to experience genuine friendliness or affectionate concern for another' (BONIME, 1966: 155). This may be the reason why Eiguer (1999: 671) feels bound to regard cynicism as 'a component of perversion'. 'The patient gives the odd impression of possessing a sense of reality and intelligence, albeit coupled with a certain contraction of his interests, which are directed primarily towards his own projects of mastery. But his thought is stimulated preferentially when it has a cause to defend. In more general terms, this will involve the setting up of a doctrine on the universality of deceit and infamy. That is the crucible of cynicism' (EIGUeR, 1999: 677, original emphasis). 'The acceptance of a cynical attitude... may help the individual to remain unaware that he actually harbors affectionate feelings towards others' (SARNOFF, 1960: 132).

\section{A SOCIO-ANALYTIC PERSPECTIVE ON BETRAYAL AND CYNICISM}

As already indicated, one - if not the crucial reason that psychoanalysis appears so inclined to a pejorative view on betrayal may be seen in the founding process of psychoanalysis itself and its early development. Amongst the early (male) followers of Freud, whoever dared to take up a different perspective on what might constitute the unconscious would run the risk of being seen as a traitor of the doctrine or - even worse - as someone who was betraying 'the father'.

This seems to be similarly true for cynicism. Psychoanalytic perspectives on cynicism appear quite narrow and neglectful of its historical and societal implications. In addition, as Sloterdijk (1988, cf. 1984) indicates, they also ignore the history of ideas, which is constituent for psychoanalysis and its inheritance. Regarding psychoanalysis as being rooted in the Greek philosophical tradition of Kynicism as a form of Cheekiness (ibid.: 101ff.), psychoanalytic perspectives on cynicism not only devalue the meaning, charm, fascination and tragedy of cynicism but betray the character of psychoanalysis as a 'thoroughly kynically inspired discipline' (ibid.: 149). In its limited focus on the inner world of the individual, psychoanalytic conceptualisations not only seem to have lost sight of the fact that modern cynicism has dramatically changed since the First World War and its aftermath (ibid.: 122), but seem to have ignored the fact that cynicism could be seen less as a symptom of private melancholia and more as an expression of a deep hopelessness and despair due to betrayal, loss and disillusionment on the public and political level and thus on the role level of the citizen. As previous modes of consciousness have lost their value, evaporated through endless suffering and substituted by defensive surrogates, cynicism has become 'a conscious choice of unconsciousness' (ibid.). 'The discontent in our culture [FreUd, 1930] has assumed a new quality: It appears as a universal, diffuse cynicism' (SLOTERDIJK, 1988: 3). 'Cynicism is one of the categories in which modern unhappy consciousness looks itself in the eyes' (ibid: : 140).

Eiguer's (1999: 673) assumption, for example, 'that cynicism takes the form of a thought and that it fuels a strategy' thus has to be seen much more as a social strategy than as an individual, private one. Understood from this perspective, cynicism as a social pattern fosters the supposition that the thoughts of the cynic are an expression of non-thinking or even 'anti-thought' rather than thinking in the Bionic sense (BIon, 1962, 1984/[1962]; cf. Hoggett, 1989). Cynicism thus further may be seen as a kind of asocial or perverse narcissism (LAWRENCE, 2003), which, as opposed to pathological, has to be seen as socially induced and re-enforced by the basic assumption of me-ness (Lawrence, Bain and Gould, 1996). ${ }^{6}$ Cynicism is thus

\footnotetext{
${ }^{6}$ Basic assumption me-ness (baM): 'Our working hypothesis is that baM occurs when people - located in a space and time with a primary task, i.e., meet to do something in a group work on the tacit, unconscious assumption that the group is to be a non-group. Only the people present are there to be related to because their shared construct in the mind of "group" is of an undifferentiated mass. They, therefore, act as if the group had no existence because if it did exist it would be the source of persecuting experiences. The idea of "group" is contaminating, taboo, impure, and, in sum, all that is negative. The people behave as if the group has no reality, and cannot ever have reality, because the only reality to be considered and taken account of is that of the individual. It is a culture of selfishness in which individuals appear to be only conscious of their own personal boundaries, which they believe have to be protected from any incursion by others. The nature of the transactions is
} 
an expression of the reification of the singleton (TURQUET, 1975), a perversion of socialism; it reveals the radical, insurmountable loneliness of the individual in a society of competing monads and dehumanises man, who must exist in a human way only in relation to others (FetsCher, 1975). And even the underlying desire that at least the cynics in their cynicism would be able to maintain or establish some relatedness amongst themselves may but appear like the rhetoric of 'workers of the world, unite!' - the equally antiquated and desperate illusion that the global workforce would be able to change its fate if it only would be able to express its solidarity.

We live in a time in which cynicism has become part of the social repertoire of coping with discontent in our culture. If we subscribe to Bion's (1957; cf. SieVERS, 1999) differentiation of the psychotic and non-psychotic parts of the personality, we may assume that all of us are prone to it. Instead of pathologically classifying someone as a cynic, we thus may assume that we all have cynical and non-cynical parts. Following this assumption, it can, from a socioanalytic perspective, be assumed that the extent to which one or the other part resonates or predominates may not primarily be a matter of individual 'character' but instead a reflection of systemic variables. That would mean that the actual scope and intensity of cynicism are an expression of the organizational context and the extent to which the actual experience of hopelessness and despair can or cannot be contained on the level of the respective social system. It thus is most likely that organizational role holders, who experience themselves as treated in a nonhuman way, reified into mere commodities or recipients of orders and unrelated to other role holders as well as to a common task, may consciously retreat into cynicism to protect themselves from being exposed to the predominating discontent.

Contrary to Bonime's (1966: 155) psychoanalytic definition of cynicism as 'a subjective disbelief in the capacity of any human being to experience genuine friendliness or affectionate concern for another', cynicism from a socio-analytic stance may well be understood as a socially shared belief that either a

instrumental, for there is no room for affect which could be dangerous because one would not know to where feelings might lead' (LAWRENCE, BaIn and Gould, 1996: 100). particular organization or social systems in general do not have the capacity to allow their role holders the experience of genuine friendliness and affectionate concern for one another. Or, to put it another way, would one actually be surprised that inmates in today's correction systems - long-term recidivists in particular - react with cynicism given the way they are treated?

Sarnoff (1960: 131) writes, from a psychoanalytic perspective, that the cynic projects into others the qualities that are constituent of himself, i.e. 'being devoid... of genuinely altruistic motives' and seeing both himself and 'all men as being exclusively preoccupied with the gratification of their own power, security, or comfort'. From a socio-analytic perspective this would appear quite appropriate and realistic. This is especially the case when 'the Other' is a shareholder - or rather an anonymous mass of shareholders with no concern other than increasing their shareholder value.

In a curious way, cynicism seems to resemble the unthought known (Bollas, 1987, 1989). On the one hand, it implies awareness or knowledge of despair and hopelessness while, on the other hand, the known despair is protected or excluded from thinking - and from (experience). As opposed to the view that the indulgence of despair is the only road towards hope, the cynic seems to be convinced that a desperate defence against despair is the only way not to be defeated by it. The avoidance of the experience of what actually is known demonstrates the similarity between cynical and psychotic dynamics - both on the level of the individual personality and the organization.

In psychoanalysis cynicism is regarded as a form of behaviour and distorted thinking of the individual caused by certain childhood experiences related to selfbetrayal and betrayal trauma. From a socio-analytic perspective, however, cynicism (and betrayal) must be regarded as socially induced by the organization (if not society or culture) and/or its respective dynamics.

\section{THREE EXAMPLES OF BETRAYAL AND CYNICISM IN ORGANIZATIONAL TRANSFORMATION}

Through what has been elaborated in this paper so far, one might assume that betrayal and cynicism in organizations are purely recent phenomena, fueled 
by the cult of the New. In fact, however, cynicism and betrayal have long been regarded as organizational issues in social science literature (in the broader sense) and in less scientific, political or praxis-oriented literature. I will illustrate this using three different examples: (1) cynicism among US prison guards as an organizationally induced reaction to enforced organizational changes; (2) the disastrous impact of organizational changes on the lives of hundreds of thousands of veterans of the Vietnam War; and (3) the cynicism of members of the German Social Democratic Party in relation to the betrayal of its original mission.

(1) Prison and police system: Cynicism was at the center of an intensive debate in the prison and police system in the US at the end of the 1970s. As Poole, Regoli and Lotz (1978), Regoli, Poole and Shrink (1979), Poole and Regoli (1980) and various other authors indicate, corrections occupations and police forces are 'a fertile breeding ground for cynicism' (REGol et al., 1979: 185). Cynicism is regarded as a defence mechanism of the prison guards, induced by their experience of frustration and disenchantment related to the conditions of their job and role requirements. Cynicism increases to the extent that 'prison guards' work relations with inmates, fellow officers, and administrators deteriorate' (Poole and ReGol, 1980: 303). They feel abandoned and betrayed by their superiors and administrators, who appear not to support their authority in role vis à vis the prisoners. As they also experience being abused by the prisoners and unsupported by their colleagues, 'they realize no sense of accomplishment or purpose. In effect, their daily work is rendered meaningless' (ibid:: 306). 'In order to survive in a setting where the work relations at all fronts are either threatening or unsupportive, cynicism may represent the type of working ideology which at least ensures one's own psychological and physical integrity. These concerns may be the only concerns over which the guard still maintains effective control' (ibid.: 313).

As Poole and Regoli (1980: 312) indicate, the cynicism of prison guards revealed in their research was not least a reaction to the betrayal they experienced as 'traditional prison roles have been affected by institutional reforms'. The new organizational structures, guided by a political movement to improve the rights of inmates and unilaterally implemented by top prison management, ultimately severely undermined the authority of the prison guards. As in some other Western countries where, in the context of privatisation of correctional institutions, inmates are turned from prisoners into customers (cf. LoNG, 1999), the guards felt left alone and betrayed. Their former commitment to the double institutional task of rehabilitation and punishment was seriously in question. Prison managements were unable to provide sufficient containment for the role conflict of the guards and the undermining of their authority. Retreat into cynical withdrawal seemed the only escape from the insight that they themselves - and not the inmates - face 'lifelong imprisonment'.

(2) Betrayal trauma in the Vietnam War: The extent to which betrayal and betrayal traumata in particular actually are induced in an organizational context further becomes obvious in a most striking way in the context of the military forces. Shay (1994, cf. 2003), in his quite shocking account of working as a psychiatrist with Vietnam veterans, describes how the experience of combat traumata in Vietnam has severely damaged and often ruined the future lives of countless veterans. (Shay estimates that about 250,000 people have been traumatised in this extreme sense in Vietnam.) He gives frightening evidence that most of these traumata had been induced by the organization and management of the military forces and the inherent cynical neglect of the dependency needs of soldiers, especially those in the lower ranks.

While the organization of armies in the past was based on a dependency culture (BION, 1962), since the 1950s (under Eisenhower) the American Department of Defence 'adopted and enhanced policies that...transformed the officer corps into business managers and technocrats' (VANDERGRIF, 2002: 89). The transfer of the New - in the form of scientific management - from the business world into the army was further enforced by Robert McNamara, Secretary of Defence during the Vietnam War, who applied to the military forces what had appeared to be appropriate for his former employer, the Ford Motor Company. He was convinced that the 'solution to any problem... was the use of systems analysis and costeffectiveness comparative analysis' (ibid.: 95). The prevalent tendency of 'making the army a business' (ibid.: 80) also fostered a personnel system that 'produces a willing servant in the bureaucracy, the wrong type of officer to be a troop leader at any echelon' (ibid.: 18). 
To the extent that soldiers were to be treated like employees and workers, military leadership was unable to provide the containment required for combat, which is an inescapable matter of life and death. Countless soldiers experienced as betrayal the disastrous conditions enforced upon them by new and not yet adequately developed management and weapon technologies and reacted to them by betrayal trauma.

Some became preoccupied with the conviction that the US government had a vested interest that not too many of them would return home (SHAY, 1994: 52). Others turned their indignant fury into irreversible rage. The betrayal of 'what's right', a term which refers to the ancient Greek thémis (ibid.: 36), borrowed from Homer's lliad (which Shay compares to the Vietnam War in his book), is of a social kind; it hurts a person by the offence against 'what's right' (ibid.: 57). Social betrayal has a most destructive effect on the feeling of continuity of values and ideals, ambitions, and activities. If certain important values are betrayed, ultimately the trustworthiness of all ideals or activities may be challenged (ibid.: 242).

I all too well remember how disconcerted I felt when, on a recent visit to a US veterans' hospital, I noticed the appalling conditions in which the 'inmates' lived. The way these veterans appeared to me and how they were kept in custody did not leave me with the impression that the nation was grateful to those who once had risked their lives - and been psychically ruined. Only when I read Shay's (1994, 2003) books some time after the visit it became strikingly obvious to me that Vietnam veterans had been seen by part of American society 'as losers and executors of a policy that had betrayed American ideals' (Reemtsma, 1998: 10). It also confirmed another observation: 'it is historically typical for returning American war veterans throughout our history to be ignored by the communities they returned to, rather than to be celebrated and cherished by them' (SHAY, 2003: 154).

Though I was not aware of it on the occasion of this visit, it is most likely that many of these veterans (the Vietnam ones in particular) apparently suffer from lifelong betrayal trauma - sadly enough, it appears to be most likely that the severe political betrayal, on which the present Iraq war is based, will not spare many soldiers a similar traumatic fate.

(3) Social Democracy: Inspired by the experience of a Social Dreaming Workshop with the Austrian
Social Democrats, I researched the early history of German social democracy. It became evident that German social democracy and its history during the relatively short period of the Weimar Republic is an even more dramatic example of organizational betrayal and cynicism.

As opposed to the two previous examples, where the New had been enforced upon an organization in destructive ways, the relatedness of the Old and the New and the inherent experience of betrayal and cynicism was different in the case of the suppressed revolution in Germany at the end of World War I. From its very beginning, at the end of the 19th century, German Social Democracy had to face the accusation of having betrayed its original target group, i.e., 'the workers'. Even though the Weimar Republic as such was a period in which 'fraud and expectations of being defrauded became epidemic' (SLOTERDIJK, 1988: 483) and had a major impact on social and political life in Germany, the focus here is on the relatively short period after the end of World War I, in 1918, when 'social democracy destroyed and hindered what was about to take place in Germany in those months: the Social Democratic revolution' (ibid.: 432; cf. HAFFNER, 1995: 6).

The Social Democratic Party, led by Friedrich Ebert, the Reichskanzler (ChANCELLOR of the REICH) and chairman of the party, squelched the revolutionary attempts of the workers, who to a major extent were either members or sympathizers of the party. Ebert was driven by the desire to reach hegemony for his party in the Reichstag in order to get a broad enough basis for enforcing social reforms and for improving the fate of the workers. As a result, he 'placed the needs of organizational survival over adherence to doctrine' (LIPSET, 1962: 19; cf. SLOTERDIJK, 1988; HAFFNER, 1995).

This did not only contribute to the predominant social and political climate of cynicism during the Weimar Republic but seriously damaged the credibility of the Social Democratic Party up to the present. 'The workers', party members and sympathizers alike, have a deeply rooted suspicion that contemporary party leaders are not able to cope with the insuperable contradiction between being the party of the working class and the unemployed and the increasing conviction 'that traditional working class politics had become obsolete in a world of globalized competition' (Bernstein, 2005). 
What has become clear from these three case examples is the often devastating impact that social betrayal can have both for an organization's membership or workforce and for the organization as a whole. As the literature on the corrections system and Shay's work on Vietnam veterans indicate, the deep feeling of betrayal and the 'flight' into cynicism or betrayal trauma on the side of organizational role holders can be understood as being socially induced by maladapted organizational transformations, i.e., by an inadequate reform of the authority structure and the role requirements of superiors and their subordinates and/or the adoption of management and leadership models that prove to be totally inadequate for the respective organizational task. The sketch on the Social Democratic Party is not only an indication of how deeply betrayals from earlier times last over time but also raises serious questions about its future and its ultimate survival.

\section{BETRAYAL AS A DEFIANCE OF MANDATED SOCIAL RELATIONSHIPS}

Following Gresson's (1982) paraphrase of betrayal as 'a unilateral breaking of faith, oneness, affinity, or trust with another' (ibid.: vii), betrayal in the context of organizations - and organizational transformation in particular - can, to a major extent, be understood as the 'defiance of mandated social relationships' (Gresson, 1982: 3; cf. Elangovan and Shapiro, 1998; Koehler and Gershoff, 2003; Morris and Moberg, 1994; SCAllen, 1993). It 'destroys the fabric of the relationships that keep our organizations operating' (REINA and REINA, 1999: 37). As betrayal always involves 'central processes of change and stability in the moral and social boundaries of collectives of people and hence in their sense of belonging and identity' (BEN-YEHUDA, 2001: $311 \mathrm{ff})$, the experience of betrayal often seems to be linked to change and to organizational transformation in particular. As some or most of the Old no longer is valid, organizational changes are most likely - to a greater or lesser extent - experienced as a loss and, in the extreme case, as deceit or robbery.

As many recent transformation processes in enterprises and corporations more or less appear forced down from top management - often with a high degree of violence (STEIN, 2004) - it is but an irony that managements and management books in particular broadly propagate a 'rhetoric focused on "commitment", "loyalty", and "trust"' (CIULLA, 2000: 153). This not only seems to confirm one of my previous working hypotheses that 'the attempt to engineer trust by management is an expression of an underlying denial of the loss of hope both with regard to the relatedness between organizational members... and the value and meaning of organizations' (Sievers, 2003b: 24; cf. Sievers, 2003a, 2003c); it equally can be assumed that the inherent betrayal is further evidence of (top) management's deep despair.

According to my own understanding and to the literature on the betrayal of work and the worker (Wolman and Calomosca, 1997; Faludi, 1999; Reina and Reina, 1999; Ciulla, 2000; Stein, 2004), the contemporary predominance of betrayal in organizations is a result of top managements' contempt towards the workforce. Management strategies like downsizing, reengineering, outsourcing, megamergers, benchmarking, and various others, all of which promise more effective business processes, profits and efficiency, predominate. The reasons articulated are not only based on the conviction that workforces were often inflated in the past and thus require downsizing or slimming via 'organizational anorexia' (STEIN, 2004: 426ff), they also reflect the contemptuous assumption that workforces have for too long lived in clover by profiting from life-long employment, high (pension) benefits, relatively low work-loads and increasing wages - an assumption that might have been true perhaps two decades ago but not today. Managements' contempt towards 'the worker' is not a recent phenomenon but can be regarded as ingrained in the relationship since early times of industrialization (Sievers, 1994: 74ff; cf. Pelzer, 2005). The contemporary increase of contempt via betrayal suggests that top management groups cannot acknowledge the chaos and despair inside themselves and their managerial roles. Instead of accepting and containing their own inner chaos and despair resulting from their own unacknowledged limitations and their powerlessness to respond adequately to demanding environmental challenges, chaos and despair are projected both into the workforce and onto apparently inadequate former management tools.

It further can be assumed that the betrayal of workforces by top management is regarded by the latter as a justified response to the betrayal they have had to 
endure from the former for far too long. Although it is true that employees have to a more or less limited extent cheated their employers, e.g., by stealing or reducing their commitment to the minimum of what is required of them in their roles, top managements' fantasy that employees have to be prosecuted and punished for their betrayal is a projection ${ }^{7}$ that ultimately serves to justify and legitimise their own behaviour as an unavoidable and adequate reaction.

\section{BETRAYAL THROUGH 'BETTERMENT' OF THE NEW}

Whereas in pre-modern times and ancient times in particular, the Old is generally considered to be better than the New, modern age has turned the hierarchy of time around. Since the 19th century, 'innovation has become a god to whom we are even today paying tribute day by day' (GIRARD, 2004: 41). Striving for the future 'also means to dissolve the links to the past and to break the supremacy of tradition - often in a quite violent manner' (KosCHORKE 2004: 144). That does not only mean that newness and novelty have become the tropes of modernity but also the speed with which the New is becoming old has increased enormously. The ironic remark of Karl Valentin, a German comedian and actor of the first half of the 20th century, that there is nothing older than yesterday's paper, has more and more become today's reality. The half-life period of knowledge, the expiry dates and the life cycles of many of our products have shrinked drastically; in fact many products are made to expire!

As the future per se almost necessarily is supposed to be better, betterment has become the predominant doctrine not only for our private lives but also

\footnotetext{
${ }^{7}$ Projection: 'Lit. Throwing in front of oneself. Hence its use in... psychoanalysis to mean "viewing a mental image as objective reality". In psychoanalysis two sub-meanings can be distinguished: (a) the general misinterpretation of mental activity as events occurring to one, as in dreams and hallucinations; and (b) the process by which specific impulses, wishes, aspects of the self, or internal objects are imagined to be located in some object external to oneself. Projection of aspects of oneself is preceded by denial, i.e. one denies that one feels such and such a wish, but asserts someone else does.... Projection of internal objects consists in attributing to someone in one's environment feelings towards oneself which derive historically from some past external object whom one has introjected' (RYCROFT, 1995/[1968]: 139).
}

for science, education, health care, industry, and economy. The respective organizations and their role holders are under unimaginable pressure to adapt to the doctrine of betterment and to be devoted to the idea of progress. As there is almost no doubt that the New per se is better than the Old, newness becomes a value in itself, obliterating traditional ways of living and working and above all most of the values on which they were based.

Contemporary capitalism reduces social, political, and economic reality into money that, as Wolfenstein (1993; cf. SIEVERS, 2003a) has elaborated, has become a universal equivalent to all values and thus the standard of values in general. As money has lost its meaning and symbolization, what counted so far as ultimate values are reduced to 'shareholder value' turning shareholders into the only relevant and 'legitimate "stakeholders" and reference group' (STEIN, 2004: 431). And as time is equally reduced into money, time loses its relatedness to the past; it is supposed to happen in the immediate present with the only function to increase future gains. As the Old, and thus the past, is split off (cf. Sievers, 2004), turned into an object of hatred, regarded as antiquated and supposed to be abolished, the New is supposed to give the guarantee to be better; it per se is promising a higher profitability and increase of shareholder value.

Whereas organizations - and corporations in particular - previously represented symbols of survival and immortality, due to their existence over generations and their offer of lifelong employment (SIEVERS, 1990, 1994), in contemporary organizations, 'the face of death is the bottom line everywhere' (STEIN, 2004: 431).

New organizational and managerial strategies like downsizing (STEIN, 1999, 2000, 2004), business process reengineering (HAMMER and CHAMPY, 1993; cf. Wolman and Calamosca, 1997; Grint and CASe, 1998; CASE, 1999; SIEVERS, 2004), shareholder value optimization (RAPPAPORT, 1986; cf. SIEVERS, 2003a), or balanced scorecard (KaPLAN and NorTON, 1996, 2001; cf. KIUNKE, 2004) are increasingly being implemented and pushed through in response to the promising economic advantages or the potential threats of globalization. These new strategies are often based on a cynically engineered 'work ethic of intimidation and fear' (STEIN, 2004: 424). 
Business process reengineering, with its rhetoric of 'Don't automate, obliterate' (HAMMER, 1990) or 'Tradition counts nothing. Reengineering is a new beginning' (HAMMER and CHAMPY, 1993: 49), is probably the most striking example of how the Old tends to be devaluated and abandoned in face of the New. More and more, and often with good reason, traditional means of organizational transformation and profit maximization in particular have proven insufficient or a total failure The way reengineering has been marketed and accepted by a vast amount of enterprises in the 1990s seems to be the incarnation of a cult of the New. The ruthlessness, boldness, and naïveté with which it has been propagated - and implemented - would previously have appeared incredible. Reengineering is based on a total neglect and obliteration of the past in which organizations and enterprises in particular functioned as reliable containers for the owners and/or shareholders and for meaningful work.

The exclusive emphasis on the improvement of business processes and thus the optimization of profit and shareholder value reduces organizational reality to a monopoly game designed to maximize profits with the lowest amount of invested capital and the rationalization of technology and resources - including those that, in the rhetoric of personnel management, have long since been referred to euphemistically as 'human'.

In a metaphoric sense, the propagators of business process reengineering and many other management strategies seem to resemble the cynic, described above, who, in his sadism, is 'demolishing beauty, of spirit and creations' (EIGUER, 1999: 671), using a 'strategy aimed at domination' (ibid.: 672), being devoid of genuinely altruistic motives, and 'essentially selfseeking along any scale of values held dear by the society of which he is a member' (SARNOFF, 1960: 131). Remaining in the metaphoric frame of the cynic, as described in psychoanalysis and applied here to the propagators of management strategies, it is not too much of a surprise that Eiguer (1999: 671) regards cynicism 'as a component of perversion'. Like cynicism, these strategies tend to take 'the form of a thought and...fuel... a strategy' (ibid.: 673) that, as indicated above, reflect a high degree of non-thinking. The propagators of those organizational and managerial strategies devoted to the cult of newness seem to be driven by a totalitarian-state-of-mind (LAWRENCE, 1995), leaving their subordinates with no choice other than acquiescence.

The biblical parable of the wineskins (e.g., GREELEY, 2004; WeILER, 2004), i.e., that 'no one puts new wine into old wineskins; otherwise the new wine will burst the skins, and it will be spilled out, and the skins will be ruined' (LUKE 5:37), is often used to illustrate the value of the New. The general assumption regarding this parable is that the new wine stands for a positive symbol and the old wine for a negative one. This, however, is not the interpretation of most wine connoisseurs and - as the theologian Eriksson (2002) convincingly indicates - is also not congruent with biblical exegesis. In Mediterranean ancient culture the Old was highly esteemed. The belief that the New is better is in itself based on a moral persuasion, which began in the 2 nd century. Commonly used as proof that Christianity is better than (Pharisaic) Judaism, the parable has not only 'served as a justification for the winning side in an ideological battle between Judaism and Christianity' (ibid.: 13) but continues to be applied to the contemporary battle for organizational betterment and its devoted service of the cult of the New.

Betrayal, when realized, is a phenomenal existential feeling and experience. The world is no longer the same as before. As the New is often devastating, it raises all kinds of 'negative' feelings and not seldom be despair. 'Issues of betrayal always involve', as BenYehuda (2001: 311ff) puts it, 'central processes of change and stability in the moral and social boundaries of collectives of people and hence in their sense of belonging and identity'. Betrayal reaches its climax when the New changes from an episode that might be 'repaired' later to a permanent reality, regarded as incontrovertible and infinite. As it is likely that the organizational strategies referred to above may soon be replaced by even newer ones - and thus by renewed betrayal -organizational role holders face even more of 'the social production of meaninglessness and rage' (Stein, 2004: 425, with reference to FALUDI, 1999).

Those who are lucky enough to have survived a first (or even subsequent) round of downsizing and betrayal by devastating organizational transformation know full well that they could be the next victims. 'The betrayal of trust and loyalty, the abrupt severing of the psychological/social contract, the utter 
discounting of human relatedness, the chronic condition of disposability, leads to self-protective measures, often unconscious, among workers and managers alike' (STEIN, 2004: 431), regardless whether they are among the survivors or not.

'Over time, employees become cynical from the cumulative effect of these bruising betrayals and lose confidence in their organizations. Employees reach the point where they expect to be betrayed' (REINA and ReINA, 1999: 6). The experience and emotional response of survivors to betrayal shapes not only their experience but also the organizational culture as a whole. In its worst case, it becomes tainted by the 'survivor syndrome' of managers and workforce alike.

\section{THE IMPACT OF THE FINANCIAL SERVICE REVOLUTION}

In the following section, I would like to emphasise the impact of a particular New on the contemporary dynamic, i.e., the financial service revolution. It can be assumed that underlying top managements' projections into the workforce - that of chaos, despair and betrayal - is the contempt and betrayal that they experience, mainly unconsciously, from shareholders and from the financial analysts of the huge investment and pension funds in particular. The main 'accomplishment' of the financial service revolution is the broadly irrefutable fact that money is all that counts in today's business world. Money, having become the measure of man means that (top) managers are not only obliged to follow the pied pipers and the tunes they are playing, but feel more controlled, disposable and thus replaceable than their predecessors. Corporate executives, at the mercy of shareholders, turn into mere henchmen of the major institutional investors and their managements. As further elaborated on a previous occasion (SIEVERS, 2003a), the financial industry sustains a vicious circle of psychotic ${ }^{8}$ projec-

\footnotetext{
${ }^{8}$ Contrary to the traditional use of the term both in psychiatry and psychoanalysis, psychosis is understood here as a way of thinking. It is mainly through the work of Melanie Klein (1952, 1959) that the experience of anxieties of a psychotic nature is regarded as a constituent dimension of the normal development of infants, and equally constitutes a part of our adult world, rooted as it is in this early experience. To acknowledge psychotic anxieties and thinking as constituent parts of the development of infants and of human development - and thus of life in general - contributes towards a depathologization of psychosis
}

tions and introjections ${ }^{9}$ sustaining a mutual collusion of defences against psychotic anxieties.

In the context of shareholder value frenzy, the value of an enterprise is reduced to a single monetary one, i.e., the shareholder value. This makes obsolete any other notion or quality. Organizations in the financial industry have no valency for anything other than the mandate they claim to have from their shareholders. The vicious cycle of psychotic transferences is not limited to the inner world of the financial industry but directly impacts other corporations and enterprises. To the extent that top corporate managements are in collusion with the institutions of the financial industry, they can be seen as having become the primary object of 'defiance of mandated social relationships' (Gresson, 1982: 3). This collusion appears to perpetuate the vicious circle of betrayal, as these top managements project the unacknowledged betrayal of the funds and their representatives into their own organizations and workforces. As the mandated relationship with the funds is tainted by defiance, top managements collude with the workforce to foster a relationship based on mutual distrust and betrayal. As contemporary managements appear to have no other choice than to adapt to the triumphant increase of the 'cult of the share', the new generation of top managers not only loses its historical autonomy but also perpetuates a psychotic circle in which everything that is not commodifiable is devalued and excluded - including its workforce, which is treated like any other resource for the exclusive sake of shareholder value optimisation.

Fuelled by psychotic anxieties and defences, the external reality in which the pension funds operate is characterized by a totalitarian mode of thinking and thus reduced to a universal money game. Limited to

and its respective anxieties (Young, 1994: 73ff). It is the notion of psychotic anxiety as the in-between state of the paranoidschizoid and the depressive position which challenges me to use the notion with organizations. Social organizations and profit-oriented organizations, in particular, often seem to cover their internal anxiety level with a somehow curious, but nevertheless normal appearance.

${ }^{9}$ Introjection: 'The process by which the functions of an external object... are taken over by its mental representation, by which the relationship with an object "out there" is replaced by one with an imagined object "inside". The resulting mental structure is variously called an introject, an introjected object, or internal object' (RYCROFT, 1995/[1968]: 87, original emphasis). 
the dual logic of either winning or losing and played in a highly complex and ever speedier fashion, this game avoids any consciousness of greed, fraud or betrayal. In cynically ignoring any other value but that of money, the game maintains demoralization by affluence. Money has but a cynical valence (SLOTERDIJK, 1988: 315).

Although both shareholder value optimisation as 'the new standard for business performance' (RAPPAPORT, 1986, original emphasis) - and thus the incarnation of the cult of the share - as well as the revolution of the financial service industry (e.g., CLARK, 2000) have become crucial for business and capitalism in a global economy for more than a decade and thus, in a sense, are not really any longer 'new', they meanwhile have become 'commandments' for the betterment through the New, elaborated above. Not taking them into account or offending against them has become a deadly sin in the global business world. To commit it almost equals eternal damnation in the sense of drastic decrease of shareholder value and ultimately bankruptcy or hostile takeover. In order to avoid this sin, top managements seem to be legitimised, if not encouraged, to regard almost anything that - according to the Ten Commandments - had previously been perceived as sin as a mere means for the improvement of profit and the increase of money. As Orwell (1956: 43) put it half a century ago, 'money worship has been elevated into a religion. Perhaps it is the only real religion - the only really felt religion - that is left to us. Money is what God used to be. Good and evil have no meaning any longer except failure and success.'

As there is striking evidence that most new management strategies only contribute to raise the value of a firm for a short time, if at all (e.g., WoLman and ColAmosCA, 1997; LURIE, 1998), it is an irony and a paradox that every new attempt to 'improve' companies by the newest, more promising innovations further nurtures the vicious circle of betrayal. To the extent that the engineering of organizational transformation is 'highly influenced and contaminated by brutality, sadism, indifference to suffering, and...magical thinking' (STEIN, 2004: 419), it is not too much of a surprise that employees, both lower management and the workforce, often and to an increasing extent, tend to react to the cynicism of top management by cynicism themselves. Cynicism results, as Teichert (1990: 100) puts it, 'when one is no longer prepared to experience betrayal, and it functions to immunize oneself against further injuries of this kind'.

\section{CONCLUSION}

What I have attempted to elaborate so far is just a sketch; neither have I intended to give a complete overview on betrayal and cynicism in the context of organizational transformation, nor do I regard this matter closed. Looking at the predominating betrayal and cynicism in contemporary organizations from the perspective chosen here, one may have the quite pessimistic impression that the business world and working life are tainted by an endless accumulation of money. What broadly is propagated as the 'new wine' has become to an incredible extent poisoned by the 'new wineskins'. For the sake of affluence and achievement of world market hegemony, this poisoning is broadly ignored by the main protagonists and profiteers. The immanent tragedy is hidden, disguised or denied by more and more betrayal and cynicism. 'Modern bourgeois economic sciences are', as Sloterdijk (1988: 315) states, 'nothing other than a higher-level non olet. In the song of the praise to the free-market economy, modernized money, as capital, has found an appropriately modern form to declare its physical and moral odorlessness'.

The socio-analytic perspective applied here has been guided by the underlying assumption that the degree of betrayal and cynicism in the context of contemporary organizational transformation is partly an expression of a psychotic global dynamic, fuelled by the new financial service industry. It would seem to be a wasted effort to imagine how this dynamic might ever be changed.

It is difficult to imagine how, in the present context, a defiance of the mandated social relationship could be overcome to create hope for a significant transformation of organizational culture. What Teichert (1990: 24) states about the realm of interpersonal relationships seems to apply here, i.e., that to the extent that the 'culprits' are not prepared to take responsibility for their deeds, to show remorse or - due to shame admit what they have done to others, committed betrayal cannot be overcome by a development of new trust. On the contrary, it leaves the betrayed ones in a state of permanent dependency on their betrayers, thus 'immortalizing' the betrayal. 
How can one imagine that top managements and workforces will ever be able to admit that they are mutual traitors? Krantz (2005: 14) has offered the idea that 'the capacity to betray from the depressive position [might be]...a developmental stage for managers and leaders'. He works with the hypothesis 'that injury is more easily overcome, and the experience of guilt, anger and sadness more easily integrated, when the betrayal occurs in the broader context of institutional purpose' (ibid.: 23). Using these thoughts, it seems to be more reasonable to imagine a reflexive strategy of betrayal, which can be contained, acknowledged and hopefully 'overcome' by leaders who have the capacity to work from the depressive position. 'Containing the experience of betrayal and converting it into useful thought' (ibid: 26) under 'normal' conditions of organizational change requires a high amount of competence on the side of the leader. To change 'psychotic betrayal' to 'depressive betrayal' appears a Herculean task that requires almost superhuman authority, strength and confidence on the part of any leader prepared to face it.

If there is some truth to what Rycroft (1992: 19) states, i.e., that 'hope is, in fact, something that circulates within that total, wider, system of relationships we call society', then perhaps in future we can collectively generate further hope in parts other than the economic realm. Developing a 'social matrix of hope' (ibid.) may help us to overcome the current predominant economic and business matrix of betrayal. Even though the wheel of history ultimately cannot be turned back, we must be aware of the fact that the New does not necessarily imply better; we may have to continually remind ourselves of the original meaning of the parable of the wineskins, i.e., that 'the old is better' (LUKE 5:39).

\footnotetext{
${ }^{10}$ Paranoid-schizoid position: 'Psychic configuration postulated by Melanie Klein in which the individual deals with his innate destructive impulses by (a) splitting both his ego and his object representation into good and bad parts, and (b) projecting... his destructive impulses on to the bad object by whom he feels persecuted. According to Klein, the paranoid-schizoid position constitutes the infant's first attempt to master its( his) death instinct and precedes the depressive position. Failure to leave the paranoid-schizoid position (i.e. to reach the depressive position) is responsible, in Klein's view, not only for many schizoid
}

Differentiation between paranoid-schizoid ${ }^{10}$ and the depressive ${ }^{11}$ dynamics offers a different perspective on the Old and the New than immaturely splitting them into regressive or progressive features (GILMORE et al., 1997: 177). Holding unshakably onto the Old or persisting in the frenzy of the New are both expressions of a psychotic dynamic. Neither position allows one to face the anxieties of the paranoidschizoid position nor of the depressive one. Over three decades ago, Eric Trist (1972: 181, cf. 1997) stated that in order to foster positive societal growth, 'a more thorough working through of the anxieties of the depressive position' must take place. Trist's position may provide a source of hope for overcoming the totalitarian-state-of-mind and the onedimensional way of thinking characteristic of the cult of the New. The seductiveness of the idea that something must be done just because it is new may come from the unconscious desire to devalue what has been arrived at and to substitute chaos and discontent with the illusion of a future of order, efficiency and happiness.

\section{Acknowledgements}

I would like to thank Gilles Arnaud, Adrian Carr, Stan Gold, Claus Hohmann, Peter Jüngst, James Krantz, John Newton, Peter Pelzer, and Jonathan Shay for their help in the process of writing this paper. I am especially grateful to Rose Mersky for her work in editing this paper to best express my ideas in English.

\footnotetext{
and paranoid disorders, but also for obsessional difficulties... in which the 'persecuting bad object' is introjected..., forming the core of the super-ego' (RYCROFT, 1995/[1968]: 125).

11 Depressive position: 'A Kleinian concept. It describes the position reached (in her scheme of things) by the infant (or by his patient in analysis) when he realizes that both his love and hate are directed towards the same object - the mother becomes aware of his ambivalence and concerns to protect her from his hate and to make reparation for what damage he imagines his hate has done' (RYCROFt, 1995/[1968]: 36).
} 


\section{REFERENCES}

AkeRström, Malin. Betrayal and betrayers: The sociology of treachery. New Brunswick: Transaction Publications, 1991.

Bain, Alastair. On socio-analysis. Socio-Analysis, 1(1), 1-17, 1999.

Ben-Yehuda, Nachman. Betrayal and treason. violations of trust and loyalty. Boulder, Colorado: Westview, 2001.

BERgler, Edmund. Zur psychologie des Zynikers (I.). Psychoanalytische Bewegung, 5(1), 19-52, 1933 a.

. Zur Psychologie des Zynikers (II.). Psychoanalytische Bewegung, 5(2), 131-66, 1933b.

BERLIN, Isaiah. Freedom and its betrayal. Six enemies of human liberty (Ed. Henry Hardy). Princeton: Princeton University Press, 2002.

Bernstein, Richard. German surprise: is Schröder giving up? New York Times, 24 May, A10, 2005.

BION, Wilfred R. Differentiation of the psychotic from the non-psychotic personalities. International Journal of Psychoanalysis, 38, 266-75, 1957.

. A theory of thinking. International Journal of Psychoanalysis, 43, 306-10, 1962.

Learning from experience. London: Karnac, 1962/1984.

Bollas, Christopher. The shadow of the object. Psychoanalysis of the unthought known. London: Free Association Books, 1987.

Forces of destiny. Psychoanalysis and human idiom. London: Free Association Books, 1989.

Bollas, Christopher. \& Sundelson, David. The new informants. The betrayal of confidentiality in psychoanalysis and psychotherapy. Northvale, New Jersey: Jason Aronson, 1995.

Bonime, Walter. Competitiveness and cynicism as factors in personality distortion. In: MeRIN, Joseph H. \& NAgler, Simon H. (eds) The etiology of neuroses. New York: Science and Behavior Books, 1528, 1966.

Boston Globe. Betrayal: The crisis in the Catholic Church. Boston: Back Bay Books, 2003.
Brennels, C. Brooks. Review of Jennifer J. Freyd, "Betrayal trauma", 1996. Psychoanalytic Books: A Quarterly Journal of Reviews, 8, 448-52, 1997.

BUCHANAN, Pat. J. The great betrayal: How American sovereignty and social justice are being sacrificed to the gods of the global economy. Boston: Little Brown, 1998.

Carotenuto, Aldo. To love to betray. Life as betrayal. Wilmette, Illinois: Chiron, 1996.

CASE, Peter. Remember reengineering? The rhetorical appeal of a managerial salvation device. Journal of Management Studies, 36(4), 419-41, 1999.

CIULLA, Joanne B. The working life. The promise and betrayal of modern work. New York: Times Books, 2000.

Clark, Gordon L. Pension fund capitalism. Oxford: Oxford University Press, 2000.

EIGUER, Alberto. Cynicism: its function in the perversions. International Journal of Psychoanalysis, 80, 671-84, 1999.

Elangovan, A. R. \& Shapiro, Debra. L. Betrayal of trust in organizations. The Academy of Management Review, 23, 547-66, 1998.

ERIKSSON, Anders. The old is good: parables of patched garment and wineskins as elaboration of chreia in Luke 5:33-39 about feasting with Jesus. Paper presented at the Heidelberg Conference on "Rhetoric, Ethics \& Moral Persuasion in Biblical Discourse", July, Queen, 2002. Available at: <http:/ /www.ars-rhetorica.net/Queen/Volume Speciallssue2/Articles/Eriksson.pdf>. (Accessed 9 September 2004.)

Faludi, Susan. Stiffed: The betrayal of the American man. New York: William Morrow, 1999.

FETSCHER, Iring. Reflexionen über den Zynismus als Krankheit unserer Zeit. In: Schwan, Alexander (ed). Denken im Schat-ten des Nihilismus. Darmstadt: Wissenschaftliche Buchgesellschaft, 1975. p. 334-45.

FreUd, Sigmund. Bruchstück einer hysterie-analyse. GW [Gesammelte Werke], 5, 161-286, S.E., 7, 7122, 1905. 


\section{REFERENCES}

A child is being beaten: a contribution to the study of the origin of sexual perversions. S.E. [Standard Edition], 14, 1919.

Civilization and its discontents. S.E. [Standard Edition], vol. 21, 64-145, 1930.

FREYD, Jennifer J. Betrayal trauma: traumatic amnesia as an adaptive response to childhood abuse. Ethics \& Behavior, 4, 307-29, 1994.

Betrayal trauma. The logic of forgetting childhood abuse. Cambridge, Massachusetts: Harvard University Press, 1996.

GarRett, Laurie. Betrayal of trust. The collapse of global public health. New York: Hyperion, 2000.

Gilmore, Thomas N.; SheA, Gregory P. \& Useem, Michael. Side effects of corporate cultural transformation. Journal of Applied Behavioral Science, 33(2), 174-89, 1997.

GIRARD, René. Nachricht von Neuerung, die drauf und drunter geht. Frankfurter Allgemeine Zeitung, 266, 13 November, 41, 2004.

Greeley, Andrew. The catholic revolution: New wine, old wineskins, and the Second Vatican Council. Berkeley: University of California Press, 2004.

GreEn, André. Potential space in psychoanalysis. The object in the setting. In: Grolnick, Simon A. (ed). Between reality and fantasy. New York: Aronson, 1978. p. 169-89.

Gresson, III, Aaron D. The dialectics of betrayal. Sacrifice, violation and the oppressed. Norwood, New Jersey: Ablex, 1982.

GRINT, Keith \& CASE, Peter. The violent rhetoric of reengineering: management consultancy on the offensive. Journal of Management Studies, 35(5), 557-77, 1998.

Grosskurth, Phyllis. The secret ring: Freud's inner circle and the politics of psychoanalysis. London: J. Cape, 1991.

Gruen, Arno. The betrayal of the self: The fear of autonomy in men and women. New York: Grove Press, 1988.

HAFFner, Sebastian. Der verrat. Berlin: Verlag 1900, 1995.
Hammer, Michael. Reengineering work: don't automate, obliterate. Harvard Business Review, 68(4), July, 104-13, 1990.

HAMmER, Michael \& ChAMPY, James. Reengineering the corporation: A manifesto for business revolution. New York: HarperCollins, 1993.

HAUBL, Rolf. Neidisch sind immer nur die anderen. Über die Unfähigkeit, zufrieden zu sein. München: C.H. Beck, 2001.

Hillman, James. Betrayal. Guild Lecture, n. 128, 527, 1964.

HIRSCH, Irwin. From helplessness to betrayal to the illusion of strength. Gender \& Psychoanalysis, 4, 291-306, 1999.

Hoggett, Paul. The culture of uncertainty. In: Richards, Barry (ed). Crises of the self. Further essays on psychoanalysis and politics. London: Free Association Books, 1989. p. 27-39.

JAEGGI, Urs. Versuch über den verrat. Darmstadt: Luchterhand, 1984.

JoSEPHS, Lawrence. The seductive superego: the trauma of self-betrayal. International Journal of Psychoanalysis, 82, 701-12, 2001.

KAPLAN, Robert S. \& NORTON, David P. The balanced scorecard. Translating strategy into action. Boston, Massachusetts: Harvard Business School Press, 1996.

KIUNKE, Sabine. Strategische unternehmensplanung und balanced scorecard. Überlegungen zu den Bedingungen der Entwicklung und Umsetzung von unternehmensstrategien auf der Basis von Zielvereinbarungen. Doctoral dissertation. Wuppertal: Bergische Universität, Fachbereich Wirtschaftsund Sozialwissenschaften, 2004.

KLEIN, Melanie. Some theoretical conclusions regarding the emotional life of the infant. In: KLEIN, Melanie; Heimann, Paula; IsaAcs, Susan \& Riviere, Joan (eds). Developments in psychoanalysis. London: Hogarth, 1952. p. 198-236,

Our adult world and its roots in infancy. Human Relations, 12, 291-303, 1959.

Koehler, Jonathan J. \& GeRSHOFf, Andrew D. Betrayal aversion: when agents of protection become agents 


\section{REFERENCES}

of harm. Organizational Behavior and Human Decision Processes, 90, 244-61, 2003.

Koschorke, Albrecht. Wissenschaftsbetrieb als wissenschaftsvernichtung. Einführung in die paradoxologie des deutschen hochschulwesens. In: $\mathrm{KIMMICH}_{\text {, }}$ Dorothee \& THUMfaHRT, Alexander (eds). Universität ohne Zukunft? Frankfurt: Suhrkamp, 142-57, 2004.

KRANTZ, James. Leadership, betrayal and adaptation. 2005. Manuscript published in: Human Relations, 59(2), 221-40, 2006.

$\mathrm{LASCH}, \mathrm{Christopher.} \mathrm{The} \mathrm{revolt} \mathrm{of} \mathrm{the} \mathrm{elites} \mathrm{and} \mathrm{the}$ betrayal of democracy. New York: W.W. Norton \& Company, 1995.

LAWrence, W. Gordon. The seductiveness of totalitarian states-of-mind. Journal of Health Care Chaplaincy, 7, October, 11-22, 1995.

1998.

. Socialdreaming@work. London: Karnac,

Thinking refracted. In: LAWRENCE, W. Gordon. Tongued with fire. Groups in Experience, London: Karnac, 2000. p. 1-30.

. Narcissism v. socialism. Governing thinking in social systems. In: LIPGAR, Robert M. \& PINES, Malcolm (eds). Building on bion: Branches. London: Jessica Kingsley, 2003.

LaWrence, W. Gordon; Bain, Alastair \& Gould, Laurence. The fifth basic assumption. Free Associations, 6(37), Part 1, again in: Tongued with fire. Groups in experience. London: Karnac, 92-119, 1996.

LIPSET, Seymour M. Introduction. In: MicheLS, Robert. Political parties. A sociological study of the oligarchical tendencies of modern democracy. New York: Free Press, 15-39, 1962.

LoNG, Susan. Who am I at work? An exploration of work identifications and identity. Socio-Analysis, 1(1), 48-64, 1999.

LuDz, Peter C. (ed). Geheime Gesellschaften. Heidelberg: Lambert Schneider Verlag, 1979.

LuHMAnn, Niklas. Trust and power. New York: Wiley, 1979.

LURIE, Jonathan. Downsizing. Unpublished thesis. Princeton University, Princeton, New Jersey, 1998.
Available at: <http://geocities.com/Wallstreet/ Exchange/4280>. (Accessed 10 February 2007.)

Miller, Alice. The drama of the gifted child: The search for the true self. London: Virago, 1995/[1979].

Thou shalt not be aware: Society's betrayal of the child. London: Pluto, 1998/[1981].

MorRIS, James H. \& MoberG, Dennis. Work organizations as contexts for trust and betrayal. In: SARBIN, Theodore R.; CARNEY, Ralph M. \& EOYANG, Carson (eds). Citizen espionages: Studies in trust and betrayal. Westport, Connecticut: Praeger, 163-87, 1994.

Orwell, George. Keep the aspidistra flying. San Diego: Harcourt Brace \& Company, 1956.

Pelzer, Peter. Contempt and organization: present in practice-ignored by research? Organization Studies, 26(8), 1.217-27, 2005.

Poole, Eric D. \& Regoll, Robert M. Work relations and cynicism among prison guards. Criminal Justice and Behavior, 7(3), 303-14, 1980.

Poole, Eric D.; Regol, Robert M. \& Lotz, Roy. Linkages between professionalism, work alienation and cynicism in large and small police departments. Social Science Quarterly, 59(3), 525-34, 1978.

Rank, Otto. The trauma of birth. New York: Robert Brunner, 1952/[1924].

RAPPAPORT, Alfred. Creating shareholder value. The new standard for business performance. New York: Free Press, 1986.

ReEMTSMA, Jan P. Vorwort zur deutschen Ausgabe. In: SHAY, Jonathan. Achilles in Vietnam. Hamburg: Hamburger Edition, 9-14, 1998.

Regoli, Robert M.; Poole, Eric D. \& Shrink, J. Occupational socialization and career development: a look at cynicism among correctional institution workers. Human Organization, 38, 183-6, 1979.

REIK, Theodor. Über den zynischen witz. In: STORFER, Adolf J. (ed). Almanach der psychoanalyse. Vol. 5. Wien: Internationaler Psychoanalytischer Verlag, 1930/[1913]. p. 204-23.

ReInA, Dennis S. \& Reina, Michele L. Trust \& betrayal in the workplace. Building effective relationships 


\section{REFERENCES}

in your organization. San Francisco: Berrett-Koehler, 1999.

Rycroft, Charles. A critical dictionary of psychoanalysis. London: Penguin Books, 1995/[1968].

. Faith, hope and charity. In: Rycroft, Charles. Rycroft on analysis and creativity. New York: New York University Press, 1992. p. 9-31.

SARNOFF, Irving. Reaction formation and cynicism. Journal of Personality, 23, 129-43, 1960.

Scallen, Eillen A. Promises broken vs. promises betrayed: metaphor, analogy and the new fiduciary principle. University of Illinois Law Review, 45(4), 897-980, 1993.

Schneiderman, Stuart. One for all and all for Freud. Book review of Grosskurth. New York Times, 17 November, 1991. Available at: <http://query. nytimes.com/gst/fullpage. html? res=9D0CE2 D61E39F934A25752C1A967958260>. (Accessed 5 May 2006.)

SHAY, Jonathan. Achilles in Vietnam: Combat trauma and the undoing of character. New York: Atheneum, 1994.

Odysseus in America. Combat trauma and the trials of homecoming. New York: Scribner, 2003.

SIEVERS, Burkard. Geheimnis und geheimhaltung in sozialen systemen. Opladen: Westdeutscher Verlag, 1974.

Thoughts on the relatedness of work, death and life itself. European Journal of Management, 8(3), 321-4, 1990.

Work, death, and life itself. Essays on management and organization. Berlin: de Gruyter, 1994.

Psychotic organization as a metaphoric frame for the socio-analysis of organizational and interorganizational dynamics. Administration \& Society, 31(5), November, 588-615, 1999.

Competition as war: towards a socioanalysis of war in and among corporations. SocioAnalysis, 2(1), 1-27, 2000.

"I will not let thee go, except thou bless me!" (Genesis 32: 26). Some considerations about the constitution of authority, inheritance, and succession. Human Resource Development International, 4, 357-81, 2001.

Your money or your life? Psychotic implications of the pension fund system: towards a socio-analysis of the financial services revolution. Human Relations, 56(2), 187-210, 2003 a.

Against all reason: trusting in trust. Organizational and Social Dynamics, 3(1), 19-39, 2003 b.

"Fool'd with hope, men favour the deceit", or can we trust in trust? (chapter 12b: Trust). In: Westwood, Robert \& CleGG, Stewart (eds). Debating organization: Point-counterpoint in organization studies. Oxford: Blackwell, 2003c. p. 356-67.

"Pushing the past backwards in front of oneself": a socio-analytic perspective on the relatedness of past, present, and future in contemporary organizations. Paper presented at the 2004 ISPSO Coesfeld Symposium: The Shadow of the Future: Psychoanalytic Perspectives on Transformation in Organizations and Society, 2004. Available at: <http://www.ispso.org/Symposia/Coesfeld/ 2004Sievers.htm>. (Accessed 10 February 2007.)

'There is nothing more worth fighting for'. Social dreaming with social democrats in Austria. In: LAWRence, W. Gordon (ed). Infinite possibilities of social dreaming in systems. London: Karnac (forthcoming), 2007.

Sievers, Burkard. \& Mersky, Rose R. Some socioanalytical reflections on vengeance and revenge. Journal of Psycho-Social Studies, 3(1), 4, e-journal, 2004. Available at: <http://www.btinternet.com/ psycho_social/Vol4/JPSS4-BSRRMI.html>. (Accessed 10 February 2007.)

The economy of vengeance: some considerations on the aetiology and meaning of the business of revenge. Human Relations, 59(1), 241 59, 2006.

Simmel, Georg. Das geheimnis. Eine sozialpsychologische skizze. Der Tag, 626, 10 December, 1907.

Das geheimnis und die geheime gesellschaft. In: Simmel, Georg. Soziologie. Leipzig: Duncker \& Humblot, 1908. p. 337-402. 


\section{REFERENCES}

The Sociology of Georg Simmel (transl. and ed. Kurt H. Wolf). New York: Free Press, 1950.

SLOTERDIJK, Peter. Cynicism - the twilight of false consciousness. New German Critique, 33, 190206, 1984.

\section{8.}

Critique of cynical reason. London: Verso,

Stein, Howard F. Todesvorstellungen und die erfahrung organisatorischen downsizing oder: Steht dein name auf Schindlers liste? Freie Assoziationi, 2, 155-85, 1999.

. In sachen verschwundener autor: von der parapraxis über die poesie zu einem Einblick in die organisationsforschung. Freie Assoziation, 3, 201-37, 2000.

Corporate violence. In: CASEY, Conerly \& EDGERTON, Robert (eds). A comparison to psychological anthropology: Modernity and psychocultural change. Oxford: Blackwell, 418-34, 2004.

TEICHERT, Wolfgang. Jeder ist Judas. Der unvermeidliche verrat. Stuttgart: Kreuz Verlag, 1990.

The cultural absence of the post-industrial society. In: EMERY, Frederick E. \& TrIST, Eric L. (eds). Towards a social ecology. Contextual appreciations of the future in the present. London: Plenum, 1972. p. 172-81.

TRIST, Eric L. New directions of hope: recent innovations interconnecting organizational, industrial, community \& personal development. Regional Studies, 13, 439-51, 1997.

Turquet, Pierre M. Threats to identity in the large group. In: KreEger, Lionel (ed). The large group: Therapy and dynamics. London: Constable, 1975. p. 87-144.
VANDERGRIFF, Donald E. The path to Victory: America's Army and the revolution in human affairs. Novato, California: Presidio, 2002.

von Matr, Peter. Liebesverrat. Die treulosen in der literatur. München: Karl Hanser, 1989.

Weller, Hans N. Neuer Wein braucht neue Schläuche. Organisationsformen und reformen im deutschen Hochschulwesen. Keynote anlässlich des Symposiums zum zehnjährigen Bestehen des Centrums für Hochs-chulentwicklung (CHE) in Berlin, 29 April, 2004. Available at: <http:// www.stanford.edu/ weiler/Vortrag_CHE.pdf>. (Accessed 10 February 2007.)

Westerlund, Elaine. Freud on sexual trauma: an historical review of seduction and betrayal. Psychology of Women Quarterly, 10, 297-309, 1986.

WinnicotT, Donald W. Ego distortion in terms of true and false self. In: xxxx (eds?) The maturational processes and the facilitation environment. London: Hogarth Press and The Institute of Psychoanalysis, 1965. p. 56-63.

Mirror role of mother and family in child development. (1967). In: WinnicotT, Donald W. Playing and reality. New York: Basic Books, 1971. p. 111-18.

Wolfenstein, Eugene V. Psychoanalytic-marxism. Groundwork. London: Free Association Books, 1993.

Wolman, William \& Colamosca, Anne. The Judas Economy. The triumph of capital and the betrayal of work. Reading, Massachusetts: Addison-Wesley, 1997.

Young, Robert M. Mental space. London: Process Press, 1994.

ZYMAN, Sergio \& BrotT, Armin. Renovate before you innovate: Why doing the new thing might not be the right thing. New York: Portfolio, 2004. 